Article

\title{
Gloria Anzaldúa's Mexican Genealogy: From Pelados and Pachucos to New Mestizas
}

\author{
Mariana Alessandri * and Alexander Stehn *(D) \\ Department of Philosophy, University of Texas Rio Grande Valley, Edinburg, TX 78539, USA \\ * Correspondence: mariana.alessandri@utrgv.edu (M.A.); alex.stehn@utrgv.edu (A.S.)
}

Received: 16 October 2019; Accepted: 18 January 2020; Published: 21 January 2020

check for updates

\begin{abstract}
This essay examines Gloria Anzaldúa's critical appropriation of two Mexican philosophers in the writing of Borderlands/La Frontera: Samuel Ramos and Octavio Paz. We argue that although neither of these authors is cited in her seminal work, Anzaldúa had them both in mind through the writing process and that their ideas are present in the text itself. Through a genealogical reading of Borderlands/La Frontera, and aided by archival research, we demonstrate how Anzaldúa's philosophical vision of the "new mestiza" is a critical continuation of the broader tradition known as la filosofía de lo mexicano, which flourished during a golden age of Mexican philosophy (1910-1960). Our aim is to open new directions in Latinx and Latin American philosophy by presenting Anzaldúa's Borderlands/La Frontera as a profound scholarly encounter with two classic works of Mexican philosophy, Ramos' Profile of Man and Culture in Mexico and Paz's The Labyrinth of Solitude.
\end{abstract}

Keywords: Gloria Anzaldúa; Mexican Philosophy; Octavio Paz; Samuel Ramos; Latin American philosophy; Chicano; Chicana; Chicanx; Mexican-Americans; Latinx philosophy

\section{Introduction}

Gloria Anzaldúa's contributions to philosophy are only lately gaining recognition (Martinez 2000, 2014; Novoa 2014; Pitts 2014, 2016; Ortega 2016; Paccacerqua 2016; Pitts 2016; Alessandri 2019; Pitts and Medina 2019; Stehn, forthcoming). The fact that other Anzaldúa scholars have focused on her relevance for understanding a variety of U.S.-American identities-e.g., Chicanx, women of color, queer, etc.- - has obscured the fact that Anzaldúa also drew from and contributed to Mexican Philosophy, especially la filosofía de lo mexicano, "a multi-generational project to pursue philosophy from and about Mexican circumstances" that flourished in mid-20th century Mexico (Vargas 2018). ${ }^{1}$ In an earlier paper, we speculated that "it is clear from her reference in Borderlands to La raza cosmica (Vasconcelos 1925) that Anzaldúa read Jose Vasconcelos, which meant she likely read Samuel Ramos (1897-1959) and Octavio Paz (1914-1998), both of whom asked what it meant to be Mexican. Their answers likely informed her own view of what it means to be Mexican-American living along the U.S.-Mexico border." After conducting archival research in the Gloria Evangelina Anzaldúa Papers at the Benson Latin American Collection at the University of Texas (UT) at Austin, we now have historical evidence that Anzaldúa read and taught both Ramos and Paz, so we are in a better position to understand how these two Mexican existentialists informed her process of writing Borderlands/La Frontera.

In Mexico, Paz and Ramos played important and widely-recognized roles in developing la filosofía de lo mexicano (Schmidt 1978; Villegas 1979; Toledo 2011; Sánchez and Eli Sanchez 2017),

1 The best introduction to la filosofia de lo mexicano available in English is the Introduction to Sánchez and Eli Sanchez (2017). Mexican Philosophy in the 20th Century: Essential Readings, Oxford University Press. The classic work in Spanish is Villegas (1979). La filosofía de lo mexicano. México, Universidad Nacional Autónoma de Mexico. 
but until now, they have been absent from Anzaldúa's recognized intellectual genealogy. A handful of scholars have discussed parallels or convergences between Paz and Anzaldúa (Lamb 2010; Novoa 2014; Belausteguigoitia 2015; Díaz 2018), but no one has presented the archival evidence for lines of direct, genealogical influence. To fill in this scholarly gap, our paper traces Anzaldúa's critical transformation of their works-especially Ramos's Profile of Man and Culture in Mexico and Paz's The Labyrinth of Solitude - to develop her own filosofía de lo mexicano in Borderlands/La Frontera. In the three sections that follow, we trace elements of Anzaldúa's text back to the work of Ramos and Paz, referring readers both to the direct, archival evidence of influence and to the indirect, textual evidence of transformation in the published version of Borderlands/La Frontera. We conclude with a reflection on our limitations and suggestions for future research.

\section{Mexican Sources Inside Borderlands/La Frontera}

In the Gloria Evangelina Anzaldúa Papers, the materials associated with the writing of Borderlands/La Frontera from 1983-1987 fill seven boxes containing 112 folders. ${ }^{2}$ In addition, we examined: (1) many of Anzaldúa's notes and papers from as far back as her undergraduate education; (2) the scholarly sources that she read, taught, and tested her students on in the late 1970s when she was a doctoral student at the University of Texas at Austin and taught "La Mujer Chicana," "The Chicana in America," and "Chicanos and Their Culture" (Sendejo 2018); and (3) the books pertaining to Mexican philosophy that Anzaldúa owned, underlined, highlighted, and wrote marginalia in.

In the published version of Borderlands/La Frontera, Anzaldúa quotes and footnotes the following Mexican sources: the norteño band Los Tigres del Norte (Anzaldúa 2012); the musicologist Vicente T. Mendoza (Anzaldúa 2012); Ismael Rodríguez, the director of Nosotros los pobres, which Anzaldúa describes as "the first Mexican film that was truly Mexican" (Anzaldúa 2012); the historian, anthropologist, and philosopher Miguel León-Portilla (Anzaldúa 2012); and the philosopher and politician Jose Vasconcelos (Anzaldúa 2012). She does not name Samuel Ramos or Octavio Paz, so it is easy to overlook them as important Mexican philosophical sources. However, consider how the opening chapter of Borderlands/La Frontera introduces and connects three different Mexican and Mexican-American identities and philosophies. Anzaldúa begins with two epigraphs. One establishes the existence of "el otro México" ["the other Mexico"] by way of song lyrics about Mexicans who inhabit the Southwestern portion of the United States that used to be (and in a sense still is) Mexico. El otro México was also the title of one of Paz's books, a translation of which Anzaldúa acquired in June 1976 (Paz 1972). ${ }^{3}$ Both Paz's book and the song lyrics by Los Tigres del Norte suggest that Mexicans who live in the United States continue being Mexican. Anzaldúa further explains: "We distinguish between mexicanos del otro lado and mexicanos de este lado. Deep in our hearts we believe that being Mexican has nothing to do with which country one lives in. Being Mexican is a state of soul" (Anzaldúa 2012). Just as the first epigraph establishes the Mexicanness of Mexicans on both sides of the U.S.-Mexico border, the second epigraph by Native American Studies scholar Jack Forbes establishes the indigeneity of Chicanos, calling them the Aztecas del norte who "compose the largest single tribe or nation of Anishinabeg (Indians) found in the United States today" (Anzaldúa 2012). As Anzaldúa explains, Mexican-Americans tend to "forget our predominant Indian genes" (Anzaldúa 2012) and "hardly ever own our Black ancestry" (Anzaldúa 2012).

In a similar way, our genealogical research has led us to conclude that scholars have largely missed Anzaldúa's Mexican philosophical ancestry. Ramos and Paz were preoccupied with the existential condition of Mexicans: the psychological, ontological, sociological, physiological,

2 Gloria Evangelina Anzaldúa Papers, Benson Latin American Collection, University of Texas Libraries, the University of Texas at Austin. Copyright (C) Gloria E. Anzaldúa. Reprinted with permission from The Gloria E. Anzaldúa Trust. All rights reserved. Subsequent references to box and folder numbers refer to materials available in this archive. References to book box numbers refer to the archival location of one of the more than 5000 books from her personal library.

3 Gloria Evangelina Anzaldúa Papers; book box 69. 
practical, and day-to-day experiences of formerly colonized subjects living in a still-colonized space. Ramos offered his famous analysis of the Mexican inferiority complex as personified in the pelado, and Paz extended the geography of lo mexicano in his analysis of Mexican-American pachucos living in California. Until now, scholars have not recognized that Anzaldúa drew upon their analyses to recognize, fight, and transform the colonizing forces that pervade the U.S.-Mexico borderlands. Chapter by chapter, Borderlands/La Frontera weaves together the histories, movements, and identities of Mexicans, Indians, and Americans of many cultures while adding a new Chicana voice to the Philosophy of Mexicanness. The process culminates in what Anzaldúa calls her own "take off" on Vasconcelos' idea of la raza cósmica: she develops la conciencia de la mestiza, which in its productive Spanish ambiguity is both a consciousness and a conscience with deep roots in the history of Mexican Philosophy. Anzaldúa's transformation of Vasconcelos connects her directly to la filosofía de lo mexicano, but we did not know how deep and wide these roots ran until we discovered new connections in the Gloria Evangelina Anzaldúa Papers. In the sections that follow, we trace elements of Anzaldúa's philosophy back to the works of Ramos and Paz, presenting both the direct, archival evidence of their influence on Anzaldúa and the indirect, textual evidence from the published version of Borderlands/La Frontera that demonstrates how Anzaldúa transformed their thinking to produce the New Mestiza, her own "take off" on la filosofía de lo mexicano.

\section{Samuel Ramos: Inferiority in Pelados and Mexican-Americans}

Through archival research, we discovered that Anzaldúa owned and read the 1972 English translation of Samuel Ramos' El perfil del hombre y la cultura en México (Ramos 1934), which is widely recognized as a foundational text for both Mexican existentialism (Toledo 2011) and la filosofía de lo mexicano (Schmidt 1978; Villegas 1979. )Since Anzaldúa often inscribed her books with her name or initials along with the date and place of acquisition, we know both when and where she obtained this copy of Ramos' book: "mayo 77, tejas Aztlán." ${ }^{4}$ By naming Texas in Spanish while locating her inscription of this book of Mexican philosophy trans-nationally and trans-historically in Aztlán, Anzaldúa prefigured the first chapter of Borderlands/La Frontera: "The Homeland, Aztlán/El Otro México." Ramos' book was required reading for Anzaldúa's Ph.D. coursework, and she required her students to read selections from it when she taught "ETS 318: Chicanos and Their Culture" at the University of Texas at UT Austin in the Summer of 1977 (Sendejo 2018). Her assignments and exam questions included questions about Ramos' chapter "Psychoanalysis of the Mexican," Paz's "The Sons of La Malinche" (from The Labyrinth of Solitude), and Vasconcelos' lecture "The Race Problem in Latin America" (delivered at the University of Chicago in 1926), alongside questions about Armando Rendón's recent Chicano Manifesto (Rendon 1971). ${ }^{5}$ Like the inscription Anzaldúa wrote on the inside cover of Ramos' book, these juxtapositions in her course construction demonstrate that she was thinking about more recent questions of Chicano/a identity in relation to classic texts that form part of the longer scholarly tradition of la filosofía de lo mexicano.

There is also archival evidence that Anzaldúa revisited Ramos' book during the period she was writing Borderlands/La Frontera. In June 1985, she wrote a list titled "Mexican Pensadores," which contains Antonio Caso, Alfonso Reyes, Samuel Ramos, Octavio Paz, Edmundo O'Gorman, Leopoldo Zea, and José Gaos. Below this list, she wrote: "Psychology of the Mexicano/Chicano" and under that: "El Perfil del Hombre y la cultura en Mexico/1934 - Samuel Ramos." She added a few bulleted themes underneath, including "fear of inferiority," "self-denigration, self-disparagement," "supposed inferiority of native culture," and "Attitude of a nation which has its origins in a highly developed autochthonous civilization that was later reduced to colonial status which the Chicano

\footnotetext{
Gloria Evangelina Anzaldúa Papers; book box 67.

Gloria Evangelina Anzaldúa Papers; box 228, folder 7.
} 
experienced twice." ${ }^{6}$ This bulleted list demonstrates that Anzaldúa's scholarly development of Chicano/a identity in relation to la filosofía de lo mexicano was not confined to her time as a graduate student and teacher at UT Austin, but extends to California, where she relocated and spent the majority of the remainder of her life, apart from the short stretches when she lived in South Bend, Indiana; Brooklyn, New York; and Northfield, Vermont.

Ramos' Profile of Man and Culture in Mexico diagnosed a kind of psychological or spiritual sickness and re-created Mexican history in an attempt to heal Mexicans and re-create Mexico, paving the way for subsequent Mexican philosophers like Paz and Anzaldúa to diagnose and re-create themselves. In developing his influential theory of the Mexican inferiority complex, Ramos goes all the way back to the conquest. He does not begin with the central "Psychoanalysis of the Mexican," which he saves for Section 3, but rather with "Imitation of Europe in the Nineteenth Century" and "The Influence of France in the Nineteenth Century" as his first two chapters. Similarly, Borderlands/La Frontera begins with a retelling of history. Just like Ramos, Anzaldúa begins with the history of conquest and colonization, but she extends the scope of Ramos' history of Mexico and Mexicans, both by including the present-day U.S. Southwest (aka Aztlán or el otro México) and by positing indigenous Mexican history (specifically, that of the Aztecs) as part of not just the Mexican past but also the future of Chicano/as.

The fundamental hypothesis that Ramos drew from Mexico's history (which Anzaldúa highlighted in her copy) was that "some expressions of Mexican character are ways of compensating for an unconscious sense of inferiority" with the result that "the Mexican undervalues himself, committing in this way an injustice to his person" (Ramos 1972). ${ }^{7}$ Like Ramos, Anzaldúa sought to "eliminate the false premises of [Mexicans'] inferiority complex" (Ramos 1972). Notice how the passage where Anzaldúa discusses the inferiority complex of the Chicana echoes the basic structure of Ramos' diagnosis:

No, it isn't enough that she is female-a second-class member of a conquered people who are taught to believe that they are inferior because they have indigenous blood, believe in the supernatural, and speak a deficient language. Now she beats herself over the head for her "inactivity," a stage that is as necessary as breathing. But that means being Mexican. All her life she's been told that Mexicans are lazy. She has had to work twice as hard as others to meet the standards of the dominant culture which have, in part, become her standards. (Anzaldúa 2012)

According to Ramos, who derived his theory of the inferiority complex from Alfred Adler, the way beyond the inferiority complex is the development of new standards that humanize what the dominant culture has rendered subhuman. Anzaldúa's critical appropriation of Ramos' work develops these new standards and humanizes women, people of color, queers, Mexican-Americans, and many other identities while paying far more critical attention to the roles of gender, language, sexuality, and spirituality in generating the Chicana's sense of inferiority. By humanizing what the dominant cultures of Texas and the United States have rendered subhuman in a second conquest and colonization of Mexicans in the United States, Anzaldúa further develops la filosofía de lo mexicano.

In Section 4: "La Herencia de Coatlicue" (note the genealogical language of herencia, i.e., inheritance or heredity), Anzaldúa describes herself and her people in terms that once again echo Ramos' analysis of Mexicans: "As a person, I, as a people, we, Chicanos, blame ourselves, hate ourselves, terrorize ourselves. Most of this goes on unconsciously; we only know that we are hurting, we suspect that there is something 'wrong' with us, something fundamentally 'wrong'" (Anzaldúa 2012). In response,

6 Gloria Evangelina Anzaldúa Papers; box 32, folder 10.

7 Anzaldúa's highlighting in the English translation of Ramos' book stops in the second chapter, which suggests that it was not the first copy she read from, since the final exam she gave for "Chicanos and Their Culture" in 1977 focused on the third chapter. The highlights are thus most likely from the time when she was writing Borderlands, as the June 1985 "Mexican Pensadores" note suggests. In any case, her markings shed new light on her project in Borderlands/La Frontera. Gloria Evangelina Anzaldúa Papers; book box 67. 
Anzaldúa says that a Chicano "fixates on drinking, smoking, popping pills, acquiring friend after friend who betrays; repeating, repeating, to prevent oneself from 'seeing'" (Anzaldúa 2012). However, Anzaldúa goes beyond Ramos' diagnosis and charts a path beyond this kind of neurosis using indigenous Mexican symbols:

We need Coatlicue to slow us up so that the psyche can assimilate previous experiences and process the changes.... Those activities or Coatlicue states which disrupt the smooth flow (complacency) of life are exactly what propel the soul to do its work: make soul, increase consciousness of itself. Our greatest disappointments and painful experiences-if we can make meaning out of them—can lead us toward becoming more of who we are. (Anzaldúa 2012)

Ramos and Anzaldúa both describe and scrutinize a wide variety of Mexican vices while developing their philosophies of Mexican culture rooted in interpretations of Mexican history and its traumas; however, Anzaldúa goes much further than Ramos in charting "a point of departure for a serious undertaking of the spiritual reform of Mexico" (Ramos 1972). For Anzaldúa, the times in our lives when we become unmoored are a chance for us to make meaning and shift the direction of our lives, if we can listen to them. What she calls "the Coatlicue state" (named after the fearsome "Serpent Skirt" deity of the Aztecs most famously represented in the colossal statue found at Tenochtitlan and housed in the National Museum of Anthropology in Mexico City) may in fact be a widespread or even universal existential phenomenon, but Anzaldúa, like Ramos, limits the diagnosis to her people and describes things using culturally-specific terms. She says that Chicanx get ruptured by Coatlicue, who "plunges us into its maw and devours us" (Anzaldúa 2012). However, by studying and accepting Coatlicue, Anzaldúa finds her way beyond the spiritual sickness that plagues Chicanas:

I see oposición e insurrección. ... I see the anger of heat or anger or rebellion or hope split open that rock, releasing la Coatlicue. And someone in me takes matters into our own hands, and eventually, takes dominion over serpents-over my own body, my sexual activity, my soul, my mind, my weakness and strengths. Mine. Ours. Not the heterosexual white man's or the colored man's or the state's or the culture's or the religion's or the parents'-just ours, mine. (Anzaldúa 2012)

By drawing upon images from all of her ancestors (unlike Ramos who consistently dismissed indigenous philosophical contributions to Mexican culture), Anzaldúa creates what Ramos called a "new humanism" and works to free herself and others from what Ramos called "the subconscious complexes which up to now have thwarted the growth of their real selves" (Ramos 1972).

Ramos explained the inferiority complex of Mexicans as the effect of historical trauma, especially from the conquest of Mexico by Spain, which "induced the sense of inferiority that was aggravated by conquest, racial commingling, and even the disproportionate magnitude of nature" (Ramos 1972). Ramos consistently took pains to clarify that the Mexican is not in fact inferior to the European but nevertheless feels inferior (Ramos 1972). Anzaldúa describes how "linguistic terrorism" has had a similarly crippling effect on Mexican-Americans in Section 5: "How to Tame a Wild Tongue," which resonates with Ramos' description of the Mexican inferiority complex but innovates by carefully analyzing the connections between language and identity.

Anzaldúa argues in favor of loving the hybrid language of Chicanos rather than being ashamed of it, but in order to defend her language, she must first describe where it comes from. Chicano Spanish reflects the life of a colonized people who are bilingual and bicultural: "We speak a patois, a forked tongue, a variation of two languages" (Anzaldúa 2012). In the same spirit as Ramos who described the "spiritual conquest" of Mexico through the primary vehicles of "language and religion" (Ramos 1972), Anzaldúa describes the way Chicanas have developed an inferiority complex under the heading "Linguistic Terrorism": 
Chicanas who grew up speaking Chicano Spanish have internalized the belief that we speak poor Spanish. It is illegitimate, a bastard language. And because we internalize how our language has been used against us by the dominant culture, we use our language differences against each other. (Anzaldúa 2012)

She further describes the painful experience in this passage:

Chicanas feel uncomfortable talking in Spanish to Latinas, afraid of their censure .... Often with mexicanas y latinas we'll speak English as a neutral language. Yet, at the same time, we're afraid the other will think we're agringadas because we don't speak Chicano Spanish. (Anzaldúa 2012)

Just as Ramos traced the Mexican practice of boasting to an inferiority complex (Ramos 1972), Anzaldúa analyzed attempts to "try to out-Chicano each other, vying to be the 'real' Chicanas, to speak like Chicanos" (Anzaldúa 2012). She does not explicitly reference Ramos' famous analysis of the pelado here $^{8}$, but we see him just below the surface of the text, especially since our archival research has uncovered the fact that the pelado is the central character type in the chapter that Anzaldúa assigned in her courses and tested her students on at UT Austin". According to Ramos, "the Mexican pelado ... constitutes the most elemental and clearly defined expression of national character" who "continually lays bare his soul" and "is an explosive being with whom relationship is dangerous" (Ramos 1972). On Ramos' account, the pelado's quarrelsome and violent behavior coupled with virile sexual boasting are in fact "illusory retaliations against his real position in life, which is a nullity" (Ramos 1972). Ramos thus infers that "the more show [the pelado] makes of courage and force, the greater is the weakness that he is trying to hide" (Ramos 1972). In a similar vein, Anzaldúa describes multiple manifestations of a linguistic inferiority complex, which stems from and in turn gives rise to acts of "linguistic terrorism." These certainly include English speakers in the United States shaming Spanish speakers: "If you want to be American, speak 'American.' If you don't like it, go back to Mexico where you belong" (Anzaldúa 2012). However, Anzaldúa also pays close attention to the way that, for example, Latinas who are fluent Spanish speakers shame Chicanas who are less fluent in Spanish or who speak forms of Chicano Spanish or Spanglish. Just as Ramos interpreted the pelado's overblown patriotism as "symbolic of the Mexican's insecurity about the value of his nationality" (Ramos 1972), Anzaldúa shows how the linguistic shaming practiced by more fluent speakers of "pure" Spanish in the United States against Chicano/as who are stronger in English or speak Spanglish reveals a parallel insecurity about the value or appropriateness of Spanish in the United States to begin with.

In existentialist fashion, Anzaldúa presents these and other psychological and spiritual maneuvers as ingenious but ultimately ineffective forms of bad faith. Influenced by Ramos, who searched for and attempted to create "our most authentic being" and called for Mexicans to "have the courage to be ourselves" (Ramos 1972), Anzaldúa's philosophy can be read as a response to the pressing need to engage in thought "based on the assumption that we are Mexicans and have to see the world in our own perspective.... Seeking knowledge in the world at large, we shall have to see it through the particular circumstances of our little Mexican world" (Ramos 1972). For Anzaldúa, this "little Mexican world" was the Texas-U.S. Southwest/Mexican borderlands, the careful study of which ultimately led her to the construction of a new mestiza consciousness and conscience that embraced the indigenous, Spanish, African, and Mexican heritages of Chicanas, adding them rather than subtracting them from their Anglo heritage.

8 Peter G. Earle, Ramos' English translator, rightly notes that "as the designation of a universally familiar social type in Mexico, [pelado] defies translation into English" (Ramos 1972, p. 57), and so we have left it untranslated.

9 Gloria Evangelina Anzaldúa Papers; box 228, folder 7. 
Anzaldúa confronts the problem of sorting good from bad Mexican elements as she undertakes the project of critically embracing all of her heritages to develop la conciencia de la mestiza. Fifty years earlier, Ramos put the problem like this:

One dangerous attitude in Mexico is the belief that an authentic national type already exists; and, in its diametrical opposition to Europeanism, this belief will inevitably lead to a reaffirmation of false Mexicanism. The best way to avoid mistakes is to remember that there is no such thing as a model for Mexican life.... The only standard in this case is a well-balanced intuition that leads us to distinguish between what is our own and what is somebody else's. (Ramos 1972)

This process of distinguishing in order to construct (not simply find) an authentic self as a member of a larger community is precisely the work that Anzaldúa does in Borderlands/La Frontera, especially in the final chapter where she describes "El camino de la mestiza/The Mestiza Way." Broadly speaking, the path to wisdom described by Anzaldúa has three steps:

1. Taking inventory: "Just what did she inherit from her ancestors? This weight on her back-which is the baggage from the Indian mother, which the baggage from the Spanish father, which the baggage from the Anglo?" (Anzaldúa 2012).

2. Critically sorting her inventory: "Differentiating between lo heradado, lo adquirido, lo impuesto," which she accomplishes as she "puts history through a sieve, winnows out the lies, looks at the forces that we as a race, as women, have been a part of. Luego bota lo que no vale, los demientos, los desencuentos, el embrutecimiento. Aguarda el juicio, hondo, y enraízado, de la gente antigua" (Anzaldúa 2012).

3. Transformation: "She reinterprets history and, using new symbols, she shapes new myths" (Anzaldúa 2012)

The end result in Borderlands/La Frontera is akin to the "new humanism" that Ramos called for while developing his own filosofía de lo mexicano. By looking deep into her own "tierra natal," "the small towns in the [Rio Grande] Valley" (Anzaldúa 2012) that constituted what Ramos would have called "the particular circumstances of [her] little Mexican world" (Ramos 1972), Anzaldúa accomplishes her mission to "search for our essential dignity as a people, a people with a sense of purpose-to belong and contribute to something greater than our pueblo" (Anzaldúa 2012). She accomplishes what Ramos called "enthusiasm and respect for Mexican things" (Ramos 1972) without fallaciously concluding that everything Mexican is good or that only Mexican things have value. However, at the same time, she extends the identity of the Mexican to include Chicanx. Her deliberateness in doing so is apparent in the way that she edited the dedication of Borderlands/La Frontera several times, considering "to all Chicanos and Mexicanos on both sides of the border" as well as "to all Mejicanos on both sides of the border no matter what they call themselves," 10 before finally deciding to dedicate the book "a todos mexicanos on both sides of the border" (Anzaldúa 2012). ${ }^{11}$

\section{Octavio Paz: Mexican-American Pachucos}

Anzaldúa's philosophy of Mexicanness understood primarily through la chicana is a profound transformation of Ramos' philosophy, but it's also a critical inversion of Paz's, whose Labyrinth of Solitude famously treated pachucos in the United States as "one of the extremes at which the Mexican can arrive" (Paz 1961). ${ }^{12}$ In October 1969, one year after Anzaldúa began her graduate studies at UT Austin,

10 Gloria Evangelina Anzaldúa Papers; box 32, folder 7.

11 Anzaldúa also considered the split term Chicano/Mexicano. Gloria Evangelina Anzaldúa Papers; box 31 , folder 13.

12 This paper focuses on Labyrinth of Solitude, but Anzaldúa's archive contains seventeen different books by Paz. 
Paz delivered a lecture there. We know, however, that Anzaldúa did not have the opportunity to attend. She worked as a teacher in the Rio Grande Valley during the regular school year to earn money for graduate school, which she attended during the summers from 1968-1972. Professionally, it was a step up from working as a "library clerk, teacher's aide, packing shed worker, and farmworker picking melons" during the day so that she could attend college at night (Anzaldúa 2009). These biographical details illustrate one of the central ideas from Paz's lecture, which Anzaldúa read later in The Other Mexico: Critique of the Pyramid. Paz claimed that "The Mexican is not an essence but a history" (Paz 1972), which foreshadowed Anzaldúa's use of history in Borderlands/La Frontera. Paz also claimed that his work on Mexicanness in The Labyrinth of Solitude was not "a search for our supposed being" but rather "an exercise of the critical imagination: a vision and, simultaneously, a revision" of what it means to be Mexican (Paz 1972). Anzaldúa's existentialist project, like Paz's, was not meant to merely describe but to transform by acts of critical scholarship and creative imagination.

It is curious that Paz wrote his philosophy of the Mexican-El laberinto de la soledad-in 1945 while living in Paris, and Anzaldúa wrote much of her philosophy of the Mexican(-American)—Borderlands/La Frontera -in 1986 while living in Vermont. It was by crossing the U.S.-Mexico border during his two-year stay as a child in the United States that Paz became conscious of himself as Mexican. Enrolled in a Los Angeles kindergarten without knowing a word of English, he could not communicate and felt like an outsider who began to ask, "at least vaguely, the same questions that Samuel Ramos asked in his Profile of Man and Culture in Mexico" (Paz 1961). In "On the Process of Writing Borderlands," Anzaldúa similarly reveals that Borderlands was written from a feeling of being an outsider who was far away from her home in the Southwest U.S.-Mexico borderlands:

I was in Vermont .... The snow was very white. The people were very white. I would walk into a store and be stared at because there are not that many people of color in Vermont.... Because of that homesickness, I began writing Borderlands. You are closer to home when you're further away. As a writer I can write about places after I've left them, rather than when I'm still there. (Anzaldúa 2009)

Anzaldúa first acquired the 1961 English translation of Paz's El laberinto de la soledad in May 1977³, just as she was finishing teaching "La Mujer Chicana" at UT Austin. Anzaldúa heavily underlined Paz's opening chapter, "The Pachuco and Other Extremes." Just as Paz described the Mexicans of Los Angeles, especially los pachucos, Anzaldúa describes the character of U.S.-Mexicans, especially los chicanos, as the product of a violent choque or "cultural collision" between Mexico and the United States (Anzaldúa 2012). Paz described pachucos as "ashamed of their origins" (Paz 1961) because of their experiences of North American racism, but unlike Paz's childhood desire to fit in, "The pachuco does not want to become a Mexican again; at the same time he does not want to blend into the life of North America" (Paz 1961). Wanting to be neither a Mexican nor a Yankee, "the pachuco actually flaunts his differences" (Paz 1961) to deny "both the society from which he originated and that of North America" (Paz 1961). In contrast, Anzaldúa's New Mestiza is the inversion of the pachuco: she works to preserve and recover her complex racial and ethnic inheritance from Mexico while embracing positive features of North American culture.

Regardless, both the pachuco and the mestiza often know the deep solitude described by Paz because they are typically rejected by both cultures. Anzaldúa underlined Paz's idea that the pachuco "vainly hopes to reconcile and conquer" both cultures, between which he "oscillates" (Paz 1961). Her underlines indicate that she was fascinated by what Paz calls the pachuco's "hybrid language and behavior" (Paz 1961). Like Ramos, Paz located the singularity of peoples in their histories and wanted all Mexicans to "reach the point of knowing ourselves to be Mexican" (Paz 1961). In a similar way, Anzaldúa wanted all Chicanx to self-consciously participate in the history that began in 1965

13 Gloria Evangelina Anzaldúa Papers; book box 3. 
"when Ceasar Chavez and the farmworkers united and I Am Joaquin was published and La Raza Unida party was formed" (Anzaldúa 2012). In the existentialist philosophies of Paz and Anzaldúa, being Mexican is an inner struggle and a political project, which gives rise to both poetry and first-person, historically situated prose. As individuals, they both reached a critical place where they wanted people to ask: "What are we? And how can we fulfill our obligations to ourselves as we are?" (Paz 1961). The difference between them is that Paz claims to be "only trying to clarify the meaning of certain experiences for my own self" (Paz 1961), whereas Anzaldúa's method of autohistoria-teoría explicitly links the project of self-knowledge to much broader social and relational histories (Pitts 2016).

Anzaldúa underlined Paz's response to Ramos' theory of the Mexican inferiority complex: "When you sense that you are alone, it does not mean that you feel inferior, but rather that you feel that you are different. Also, a sense of inferiority may sometimes be an illusion, but solitude is a hard fact. We are truly different. And we are truly alone" (Paz 1961). Anzaldúa also addresses solitude in Borderlands/La Frontera, but she does not mistake it for a "hard fact." Paz wrote, and Anzaldúa underlined: "Yes, we withdraw into ourselves, we deepen and aggravate our awareness of everything that separates or isolates or differentiates us" (Paz 1961). However, Anzaldúa develops a keener understanding of how to find our way out of the labyrinth, ending the prose portion of Borderlands/La Frontera with her vision for el día de la Chicana y el Chicano: "On that day I bare my soul, make myself vulnerable to friends and family by expressing my feelings. On that day I affirm who we are.... On that day I gather the splintered and disowned parts of la gente Mexicana and hold them in my arms. Todas las partes de nosostros valen" (Anzaldúa 2012).

Paz believed that the Mexican "shuts himself away to protect himself. His face is a mask and so is his smile" (Paz 1961). Much like Ramos, Paz claimed that mistrust characterizes the Mexican man because the world is a conquistador (Paz 1961; Ramos 1972). Paz diagnoses all Mexicans as hijos de la Chingada who are fundamentally alone (Paz 1961). The Mexican woman, in turn, had no will of her own, according to Paz: "Her body is asleep and only comes really alive when someone awakens her" (Paz 1961). Anzaldúa's copy of Paz's Labyrinth has a great deal of highlighting, underlining, and marginalia where Paz discusses women, gender, or sexuality. One can imagine her cringing at passages like this one: "Women are inferior beings because, in submitting, they open themselves up. Their inferiority is constitutional and resides in their sex, their submissiveness, which is a wound which never heals" (Paz 1961). However, even Paz himself revealed some self-doubt concerning his pronouncements on gender, as this passage underlined and starred by Anzaldúa indicates:

Of course we should ask the Mexican woman for her own opinion, because this "respect" [shown to men by women] is often a hypocritical way of subjecting her and preventing her and preventing her from expressing herself. Perhaps she would usually prefer to be treated with less "respect" (which anyway is granted to her only in public) and with greater freedom and truthfulness; that is, to be treated as a human being rather than as a symbol or function. (Paz 1961)

Like both Ramos and Paz, Anzaldúa's filosofia de lo mexicano takes a critical look at Mexican culture with the hope that confronting and diagnosing their cultural sicknesses might prove spiritually curative, but her insights are often even more critical because she consistently examines Mexican culture through the lenses of gender and sexuality. Anzaldúa used roughly one page of Borderlands/La Frontera to describe why Mexican-American machos exist: they have been oppressed and shamed by the Anglo. However, they, in turn, oppress, shame, and suffer from "a false machismo which leads him to put down women and even to brutalize them" (Anzaldúa 2012). Anzaldúa describes the macho's behavior in this poetic passage: "To wash down the shame of his acts, of his very being, and to handle the brute in the mirror, he takes to the bottle, the snort, the needle, and the fist" (Anzaldúa 2012). She concludes that while she may understand the behavior of machos, she refuses to excuse, condone, or put up with it. 
Anzaldúa recognized Paz's analysis of women as one-dimensional, but nevertheless found his literary and philosophical profile of Mexicans insightful. For example, Paz's fourth chapter title focuses only on the "Sons of Malinche," but still contains a great deal of insight into the "traits of a subjected people" (Paz 1961), which Anzaldúa critically extends to discuss the lived experience of women, especially Chicanas. Following Ramos, Paz located the heart of Mexican psychology in a long history of conquest and colonization, with the end result that "the Mexican does not want or does not dare to be himself" (Paz 1961). In the margin right next to this passage, Anzaldúa wrote: "internalized oppression orig. from outside." Paz ended his chapter with this passage characterizing the Mexican's rejection of his origins:

The Mexican does not want to be either an Indian or a Spaniard. Nor does he want to be descended from them. He denies them. And he does not affirm himself as a mixture, but rather as an abstraction: he is a man. He becomes the son of Nothingness. His beginnings are in his own self. (Paz 1961)

Again, Anzaldúa's New Mestiza inverts these ways of being Mexican along two axes, both by acknowledging her Indian and Spanish (as well as Anglo) inheritance and by affirming herself as mestiza, as someone whose origins lie outside of herself. In the language of Ramos and Paz, she dares to be herself as Mexican, understood in all its complexity and fullness.

Anzaldúa also underlined various sections of Paz's Labyrinth dealing with rebellion or revolution as attitudes that characterize the Mexican as opposed to the North American penchant for working toward gradual reform. For example:

The [Mexican] revolutionary is always a radical, that is, he is trying to correct the uses themselves rather than the mere abuses of them. Almost all the criticisms I heard from the lips of North Americans were of the reformist variety: they left the social or cultural structures intact and were only intended to limit or improve this or that procedure. (Paz 1961)

The "Movimientos de rebeldia y las culturas que tracionan" chapter of Borderlands/La Frontera resonates with Paz's interpretation of the Mexican Revolution as central to what it means to be Mexican. Anzaldúa traces her own rebellion and that of Chicanx further back, not just to Mexican Independence from Spain, but back to indigenous resistance against Spanish conquest and colonization, writing: "My Chicana identity is grounded in the Indian woman's history of resistance" (Anzaldúa 2012). Despite her upbringing as a "good" Mexican girl who was supposed to cook, clean, and prepare herself for a husband, Anzaldúa writes:

At a very early age I had a strong sense of who I was and what I was about and what was fair. I had a stubborn will. It tried constantly to mobilize my soul under my own regime, to live life on my own terms no matter how unsuitable to others they were. Terca. Even as a child I would not obey. I was "lazy". Instead of ironing my younger brothers' shirts or cleaning the cupboards, I would pass many hours studying, reading, painting, writing. (Anzaldúa 2012)

Compared to Ramos and Paz, Anzaldúa is more rebellious, creative, and deliberate in how she not only criticizes but also re-visions and re-constructs Mexican culture. She was not simply a reader of Paz, but sought to improve upon his descriptions. For example, in a passage that echoes Paz's claim that woman "transmits or preserves" rather than creates cultural values (Paz 1961), Anzaldúa writes: "Culture forms our beliefs.... Dominant paradigms, predefined concepts that exist as unquestionable, unchallengeable, are transmitted to us through the culture. Cultures is made by those in power-men. Males make the rules and laws; women transmit them" (Anzaldúa 2012). However, thanks to the strength of her rebellion, Anzaldúa says she was able "to mobilize my soul under my own regime, to live my life on my own terms no matter how unsuitable to others they were" (Anzaldúa 2012). 
After "Entering Into the Serpent" (Section 3) and recovering "La herencia de Coatlicue" (Section 4), i.e., after gathering further strength and creative resources from "the Indian woman's history of resistance" (Anzaldúa 2012), Anzaldúa re-creates Chicanx language and culture in "How to Tame a Wild Tongue" (Section 5). She writes:

I am cultureless because, as a feminist, I challenge the collective cultural/religious male-derived beliefs of Indo-Hispanics and Anglos; yet I am cultured because I am participating in the creation of yet another culture, a new story to explain the world and our participation in it, a new value system with images and symbols that connect us to each other and to the planet. (Anzaldúa 2012)

Anzaldúa was drawn to descriptions, especially those articulating differences between peoples, e.g., how Chicanas are different from Mexicans and Anglo-Americans. For instance, Anzaldúa highlighted, put an asterisk by, and circled the page number of a long passage written by Paz on the difference between Mexicans and the North Americans, writing the marginal note "N/A vs Mexicano" out to the side (Paz 1961). Anzaldúa used descriptions like these from Paz to get to know herself and find her people's place in the world, but she also tries to steer clear of essentialism, writing: "There is no one Chicano language just as there is no one Chicano experience" (Anzaldúa 2012). Like Paz and Ramos, Anzaldúa claims both universality and uniqueness for the Mexicans who call themselves Chicanos:

Nosostros los Chicanos straddle the borderlands.... Among ourselves we don't say nosotros los americanos o nosotros los españoles o nosotros los hispanos. We say nosotros los mexicanos (by mexicanos we do not mean a national identity but a racial one. We distinguish between mexicanos del otro lado and mexicanos de este lado. Deep in our hearts we believe that being Mexican is a state of soul—not one of mind, not one of citizenship. (Anzaldúa 2012)

Anzaldúa's work offers rich philosophical descriptions of los mexicanos de este lado (i.e., Chicanx), but she always recognizes that the experiences of both persons and peoples are unique. Here, we are once again reminded of Paz's claim that "The Mexican is not an essence but a history," as well as his rejection of "a search for our supposed being," in favor of creating "a vision and, simultaneously, a revision" of what it means to be Mexican (Paz 1972).

As poets, Paz and Anzaldúa were exceptionally attentive to language. Furthermore, while Anzaldúa goes beyond Paz in terms of the linguistic hybridity of her textual production - using Spanish, English, Tex-Mex, Spanglish, Nahautl, and more-it is still important to read Paz as one of her ancestors who wrote: "For us, writing means breaking down the Spanish language in a way that it becomes Mexican without ceasing to be Spanish" (Paz 1961). Anzaldúa wrote in precisely this way but on an even wider front: writing Chicana philosophy in English without ceasing to be Mexican, writing Mexican philosophy in Spanish without ceasing to be American, writing in both Spanish and English to be Chicana. She thus creatively extends what Paz characterized as "a search for ourselves, which have been deformed or disguised by alien institutions, and for a form that will express them" (Paz 1961).

Anzaldúa's final prose chapter is titled "La consciencia de la mestiza/Towards a New Consciousness" and is filled with descriptions of the New Mestiza, who turns out to be the best possible mix of cultures. The New Mestiza thus stands precisely as a counterpoint to the pachuco (Belausteguigoitia 2015), who on Paz's analysis rejects both his Mexican heritage and his American identity, whereas the New Mestiza proudly embraces both. Anzaldúa's vision effectively serves as a response to Paz's claim that "a Mexican philosophy would have to take into account not only the ambiguity of our tradition but also our will to be" (Paz 1961). Anzaldúa's New Mestiza develops a "tolerance for contradictions, a tolerance for ambiguity. She learns to be an Indian in Mexican culture, to be Mexican from an Anglo point of view. She learns to juggle cultures. She has a plural personality, she operates in a pluralistic mode" (Anzaldúa 2012). Or, in the language of Paz, "To be oneself is always to become 
that other person who is one's real self, that hidden promise or possibility" (Paz 1961). Anzaldúa utilizes her mestiza consciousness to take step after step "towards liberation from cultural domination" (Anzaldúa 2012) that takes many forms in terms of race, gender, class, language, religion, nationality, and more. Anzaldúa's language of liberation is once again reminiscent of Paz, who wrote: "Women are imprisoned in the image masculine society has imposed upon them; therefore, if they attempt a free choice it must be a kind of jail break" (Paz 1961). Anzaldúa attempted precisely such an escape toward freedom, and the writing of Borderlands/La Frontera was liberating for not just her but for a wide variety of others (Keating and González-López 2011).

\section{New Directions in the Archival and Genealogical Study of Anzaldúa and Latinx Philosophy}

It is the hybridity of both Anzaldúa and her text that have made her such an influential figure in the United States and the world, and yet she is no less Mexican: "Indigenous like corn, like corn the Mestiza is a product of cross-breeding, designed for preservation under a variety of conditions. Like an ear of corn-a female seed-bearing organ-the mestiza is tenacious, tightly wrapped in the husks of her culture" (Anzaldúa 2012). Reading Anzaldúa genealogically in relation to Paz and Ramos, we have attempted to demonstrate a continuity between Mexican and Mexican-American philosophy. Indeed, the moment that Paz described as "one of the most unjust wars in the history of imperialist expansion, [which] deprived us of over half our territory" (Paz 1961) is precisely the moment that created Chicanos in Anzaldúa's re-telling, even though they did not self-consciously become a people until the beginning of the Chicano Movement in the 1960s. Just as Paz claimed that Mexico searched "for its own true self during the Revolution" (Paz 1961), Anzaldúa portrays La Causa as not just a political movement but also as a quest for self-knowledge. Paz named Ramos' Profile as "our first serious attempt at self-knowledge" (Paz 1961, p. 159); Anzaldúa named Corky Gonazalez's Yo Soy Joaquin. In sum, Anzaldúa situated herself in a broader Mexican philosophical quest for self-knowledge, la filosofía de lo mexicano, while extending it beyond the historical and geographical boundaries of what today is known as Mexico. Not only is Anzaldúa's language obviously more inclusive in terms of both gender and language than Paz's or Ramos's, her description of nosotros los Mexicanos is also more concrete and hopeful. Nevertheless, she notes that before recognizing and adopting a mestiza consciousness, Chicanx will have to grapple with the kind of shame and solitude that Ramos and Paz diagnosed as part of the colonial history of Mexicans, now translated by Anzaldúa into a North American context.

Our essay provides a genealogical reading of only two of Anzaldúa's Mexican sources. The scholarly downside to the fact that Anzaldúa was such a voracious reader and wide-ranging thinker is that we cannot achieve an exhaustive understanding of her influences or ideas. Nevertheless, reading Anzaldúa in the Mexican tradition of Ramos and Paz opens new directions for research and philosophical dialogues while contributing to the larger, ongoing project of examining the historical and genealogical connections between Latin American and Latinx philosophy. Tracing Anzaldúa's genealogy to Ramos and Paz also obviously points to a longer line of Mexican philosophers. Given her voracious appetite for Mexican philosophy, had Anzaldúa lived longer, she would almost certainly have encountered los hiperiones, the mid-20th century Mexican existentialists including Emilio Uranga (1921-1988), Jorge Portilla (1918-1963), Luis Villoro (1922-2014), Ricardo Guerra (1927-2007), and Joaquín Sánchez MacGrégor (1925-2008). We believe that Uranga's concept of zozobra would have been of particular interest to Anzaldúa, as it names the Mexican condition of unsettledness or "insufficiency, groundlessness, and loss" stemming from identification with neither the European Conquistador nor the Indigenous Mexican (Sánchez 2016, 2019). In fact, zozobra might be a more historically accurate term for the Mexican-American predicament than Anzaldúa's choice of the Nahuatl term nepantla (Antuna 2018). Other scholars curious to see what new directions Anzaldúa's other genealogies might lead us could further explore any of these trajectories, or countless more.

Author Contributions: Both authors contributed equally to the conceptualization, methodology, validation, formal analysis, investigation, resources, writing, reviewing, and editing of this article. All authors have read and agreed to the published version of the manuscript. 
Funding: This research received no external funding.

Acknowledgments: The authors would like to thank the staff at the Gloria Evangelina Anzaldúa Papers in the Benson Latin American Collection at the University of Texas Libraries. They were extremely helpful with our requests to examine all the archival material referenced in this paper.

Conflicts of Interest: The authors declare no conflict of interest.

\section{References}

Alessandri, Mariana. 2019. Three Existentialist Readings of Gloria Anzaldúa's Borderlands/La Frontera. Cuadernos de ALDEEU 34: 117-35.

Antuna, Marcos de R. 2018. What We Talk About When We Talk About Nepantla: Gloria Anzaldúa and the Queer Fruit of Aztec Philosophy. Journal of Latinos and Education 17: 159-63. [CrossRef]

Anzaldúa, Gloria. 2009. The Gloria Anzaldúa Reader. Durham: Duke University Press.

Anzaldúa, Gloria. 2012. Borderlands/La Frontera: The New Mestiza. San Francisco: Aunt Lute Books.

Belausteguigoitia, Marisa. 2015. Introducción. Borderlands/La frontera: La Nueva Mestiza. Edited by Gloria Anzaldúa. México: Universidad Nacional Autónoma de México, Programa Universitario de Estudios de Género, pp. 13-44.

Díaz, Kim. 2018. A Process Metaphysics and Lived Experience Analysis of Chicanxs, Spanglish, Mexicans and Mexicanidad. Journal of World Philosophies 3: 44-52.

Keating, AnaLouise, and Gloria González-López. 2011. Bridging: How Gloria Anzaldúa's Life and Work Transformed Our Own. Austin: University of Texas Press.

Lamb, Danielle. 2010. "Hijos de la madre chingada" or New Mestiza: Paz and Anzaldúa. Rupkatha Journal on Interdisciplinary Studies in Humanities 2: 282-93. [CrossRef]

Martinez, Jacqueline M. 2000. Phenomenology of Chicana Experience and Identity: Communication and Transformation in Praxis. Lanham: Rowman \& Littlefield.

Martinez, Jacqueline M. 2014. Culture, Communication, and Latina Feminist Philosophy: Toward a Critical Phenomenology of Culture. Hypatia 29: 221-36. [CrossRef]

Novoa, Adriana. 2014. Places of Resistance, Bodies of Assimilation: Spanish American Intellectual Tradition in Gloria Anzaldua's Thought. Inter-American Journal of Philosophy 5: 101-25.

Ortega, Mariana. 2016. In-Between: Latina Feminist Phenomenology, Multiplicity, and the Self. Albany: SUNY Press. Paccacerqua, Cynthia M. 2016. Gloria Anzaldúa's Affective Logic of Volverse Una. Hypatia 31: 334-51. [CrossRef] Paz, Octavio. 1961. The Labyrinth of Solitude: Life and Thought in Mexico. New York: Grove Press.

Paz, Octavio. 1972. The Other Mexico: Critique of the Pyramid. New York: Grove Press.

Pitts, Andrea J. 2014. Toward an Aesthetics of Race: Bridging the Writings of Gloria Anzaldúa and José Vasconcelos. Inter-American Journal of Philosophy 1: 80-100.

Pitts, Andrea J. 2016. Gloria E. Anzaldúa's Autohistoria-teoría as an Epistemology of Self-Knowledge/Ignorance. Hypatia 31: 352-69. [CrossRef]

Pitts, Andrea J., and José Medina. 2019. Theories of the Flesh: Latinx and Latin American Feminisms, Transformation, and Resistance. New York: Oxford University Press.

Ramos, Samuel. 1934. El perfil del hombre y la cultura en México. México: Imprenta Mundial.

Ramos, Samuel. 1972. Profile of Man and Culture in Mexico. Austin: University of Texas Press.

Rendon, Armando B. 1971. Chicano Manifesto. New York: Macmillan.

Sánchez, Carlos Alberto. 2016. Contingency and Commitment: Mexican Existentialism and the Place of Philosophy. Albany: State University of New York Press.

Sánchez, Carlos Alberto. 2019. (M)Existentialism. The Philosophers' Magazine 1: 82-88. [CrossRef]

Sánchez, Carlos Alberto, and Robert Eli Sanchez Jr., eds. 2017. Mexican Philosophy in the 20th Century: Essential Readings. Oxford: Oxford University Press.

Schmidt, H. C. 1978. The Roots of Lo Mexicano: Self and Society in Mexican Thought, 1900-1934. Austin: University of Texas. Sendejo, Brenda. 2018. The Space in Between: Exploring the Development of Chicana Feminist Thought in Central Texas. In Chicana Movidas: New Narratives of Activism and Feminism in the Movement Era. Edited by Espinoza Dionne, María Eugenia Cotera and Maylei Blackwell. Austin: University of Texas Press. 
Stehn, Alexander V. Forthcoming. Teaching Gloria Anzaldúa as an American Philosopher. In Teaching Borderlands: Approaches to Teaching Gloria Anzaldúa. Edited by Norma E. Cantú, Candace de Leon-Zepeda and Margaret Cantu-Sanchez. Tucson: University of Arizona Press.

Toledo, Roberto Domingo. 2011. Existentialism and Latin America. In Continuum Companion to Existentialism. Edited by Felicity Joseph, Jack Reynolds and Ashley Woodward. New York: Continuum.

Vargas, Manuel. 2018. Review of Mexican Philosophy in the 20th Century: Essential Readings. Notre Dame Philosophical Reviews. Oxford: Oxford University Press.

Vasconcelos, José. 1925. La raza cósmica: misión de la raza iberoamericana. Paris: Agencia mundial de librería. Villegas, Abelardo. 1979. La filosofía de lo Mexicano. México: Universidad Nacional Autónoma de Mexico.

(C) 2020 by the authors. Licensee MDPI, Basel, Switzerland. This article is an open access article distributed under the terms and conditions of the Creative Commons Attribution (CC BY) license (http://creativecommons.org/licenses/by/4.0/). 